\title{
Ponkin I.V. direct objects of offence at committing of the acts oriented to an insult of religious feelings of believers and to humiliation of their human dignity
}

\begin{abstract}
The article is devoted to research of the direct groups of objects and actually objects of illegal offence (objects of direct influence, manipulations) at committing of the actions oriented to an insult of religious feelings of believers and to humiliation of their human dignity in connection with their confession of religion (on the grounds of religious belief).

Keywords: criminal law, religious feelings of believers, human dignity of believers, insult of religious feelings of believers, humiliation of human dignity of believers, religious order
\end{abstract}

Volume 5 Issue 5 - 2017

\author{
Igor $\vee$ Ponkin \\ Professor of Department of the State and Municipal \\ Administration of the Institute of Public Administration and \\ Civil Service of the Russian Presidential Academy of National \\ Economy and Public Administration, Russia
}

Correspondence: Igor V Ponkin, Doctor of Law, Professor of Department of the State and Municipal Administration of the Institute of Public Administration and Civil Service of the Russian Presidential Academy of National Economy and Public Administration (Moscow, Russia) (IPACS, RANEPA), State Professor, 82/I, Prospect Vernadskogo, Moscow, I I 957I, Russia, Email i@lenta.ru

Received: November 13, 2017 | Published: December 21, 2017

\section{Introduction}

In the field of extremist activity counteraction there is a number of complex problematic issues of the content interpretation of the reference concepts of "insult of religious feelings of believers", "humiliation of human dignity of believers on the religion grounds", etc. The quality of legal qualification of the acts in such cases depends on accurate understanding, comprehensively exact legal interpretation, and explanation of the essence of these concepts, features, and limits of the opportunities of their application in jurisprudence. It is important, as well, for understanding of the limits of where the freedom of selfexpression comes to an end (thoughts, words, creativity) and where the protected by law (including criminal law) area of religious feelings begins. And on the other hand, - for understanding of where the limits of intervention of the state to the sphere of self-expression freedom are located for the purposes of criminal legal protection and protection of religious feelings and the personal dignity of believers.

\section{Main part}

In terms of law, the object of criminal offence of "blasphemers" and "scoffers" is not God at all. Though this is the way how unreasonably the defenders of the persons, who publicly take "blasphemous" and "sacrilegious" actions, understand it, in a false manner appealing to the idea that this is a theological issue which is not subject to judicial proceedings, owing to this fact. Actually, the object of criminal offence in such situations is people (believers), their rights, freedoms and legitimate interests, their human dignity and religious feelings. The object of criminal offence in such situations is public interests connected with the need of protection and protection of personal dignity of believers, including public interests in the field of public safety and, in general, the social order. ${ }^{1}$ The specifics of this sphere of relations, however, is in the fact that the specified objects are exposed to illegal offence, act as the objects of such offence indirectly, implicitly. And this, among other, significantly complicates the task for forensic experts when carrying out examinations in such cases. It is reasonable to address to the question, what exactly (in terms of law), directly is (is admitted, is to be admitted) the object of illegal offence in extremist crimes of the considered group. Today, in Russia, judicial and other law-enforcement practices in relation to the cases of human dignity humiliation and insult of believers' religious feelings have been accumulated intensively.

We will highlight the most high-profile of such cases:

i. Criminal case on action «Caution, religion!» («art exhibition»), opened on January 14, 2003 in the Sakharov Center (Moscow);

ii. Criminal case on action « Forbidden Art - 2006» («art exhibition») in March 7-31, 2007 in the Sakharov Center (Moscow);

iii. Series of articles of Sergei Bychkov in the newspaper «MoskovskyKomsomolets» (1995-2007); ${ }^{2}$

iv. anti-Islamic book of R.A. Silantyev «The Newest History of the Islamic Community of Russia» (Moscow, 2005);

${ }^{1}$ See: Ponkin IV. Teorijagosudarstvennogoupravlenija: soderzhanieponjatija «porjadok». Theory of public administration: the content of the concept of «Order»]. Administrative Law and Process. 2016;11:8-10.

${ }^{2}$ Ponkine IV. Haine du journaliste du journal «Moskovskykommsomoletse» SergueyBychkovcontreEgliseOrthodoxeRusseRecueil des documents. Moscou: BukiVedi; 2008. 
v. Criminal case on action of group («feminist protest punk rock group») «Pussy Riot» inside Moscow's Cathedral of Christ the Savior in February 21, 2012;

vi. Author's play of Timofey Kulyabin of opera «Tannhäuser» (specific variation) in Novosibirsk Opera and Ballet Theatre in December 20, 2014;

vii. «Art exhibition» «Sculptures, which we do not see» in the Central Exhibition Hall «Manezh» in Moscow (August 2015);

viii. Film «Matilda» directed by Alexey Uchitel and was shown in the fall of 2017 in Russia; ${ }^{6}$

ix. Book of Yu.A. Brodsky Solovki. Labyrinth of Transfiguration, etc.

A full list of such shares would occupy the entire volume of this article. In several of the cases, the author was engaged as a forensic expert. Accordingly, this article is based on a large-scale scientific author's analysis of such cases. The analysis of the standards of the Russian and foreign criminal (anti-extremist) legislation, ${ }^{8}$ and also legal precedents based on such norms gives the necessary and sufficient grounds for allocation of the following direct groups of objects and actually objects of illegal offence (objects of direct influence, manipulations) at committing of the actions oriented to an insult of religious feelings of believers and to humiliation of their human dignity in connection with their confession of religion (on the grounds of religious belief):

I. Images of persons (personalities) in respect of which believers carry out religious worship or religious honoring or express special religious respect:

a. Images of the person in respect of which believers carry out religious worship (God, the image of God);

b. Images of persons in respect of which believers carry out religious honoring (in orthodox Christianity - the canonized church-wide church or locally venerated sanctified, etc.);

c. Images of persons in respect of which believers express special religious respect and the authority of which is inseparably

\footnotetext{
${ }^{3}$ Abramènkova VV, Ponkine IV, Troytsky VJ.Hainereligieuse: l'action "pank - Te Deum" du groupe "Pussy Riot" 21 Février 2012 dans les locaux de la Cathédrale du Christ-Sauveur de l'ÉgliseChrétienneOrthodoxe Russia Stato, Chiese e pluralismoconfessionale. - 4 febbraio 2013. 4. http://www statoechiese.it/images/uploads/articoli pdf/ponkinem haine.pdf.

${ }^{4}$ [Protecting the human dignity of believers: Expertises and materials on cases of insulting religious feelings and degrading the dignity of Christian believers. In: Ponkin IV, Editors. Moscow: BukiVedi; 2017;300:168-205.http://morallaw.ru/files/Zash chel dost ver expertise mat 2017.pdf.

${ }^{5}$ Protecting the human dignity of believers: Expertises and materials on cases of insulting religious feelings and degrading the dignity of Christian believers In: Ponkin, Editors. Moscow: BukiVedi; 2017;300:113-125. http://moral-law. $\mathrm{ru} /$ files/Zash_chel_dost_ver_expertise_mat_2017.pdf.

${ }^{6}$ Protecting the human dignity of believers: Expertises and materials on case of insulting religious feelings and degrading the dignity of Christian believers In: Ponkin, Editors. Moscow: BukiVedi; 2017;300:10-70. http://moral-law.ru/ files/Zash_chel_dost_ver_expertise_mat_2017.pdf.

${ }^{7}$ Protecting the human dignity of believers: Expertises and materials on cases of insulting religious feelings and degrading the dignity of Christian believers In: Ponkin, Editors. Moscow: BukiVedi; 2017;300:100-112.http://moral-law. ru/files/Zash chel dost ver_expertise mat_2017.pdf.

${ }^{8}$ Ponkin $\quad I V$. In $-{ }^{-}$meritoallatuteladeisentimentireligiosi delladignitàindividualedeicredenti.DirittoPenaleContemporaneo. 2016.
}

connected with the authority of the religious organization (or even religion) in general: heads of religious organizations, ${ }^{9}$ priests (religious attendants), monks, theologians, etc., especially authoritative among believers, both living and deceased;

d. Generalized image of the priest (religious attendant) of this particular religion during lawful execution of official (religious) duties (holding a church service, other religious practice, or a ceremony included) or in connection with such execution of the specified duties.

II. The main religious symbols in respect of which believers carry out religious worship or religious honoring, or concerning which believers are most sensitive regarding the human dignity and the religious feelings;

III. Religious texts in respect of which believers carry out religious worship or religious honoring, or in respect of which believers are most sensitive:

a. The sacred book (sacred books, Scriptures) of the religion in general as a particular (historically existing) text;

b. Substantially key, widely usable and/or recognizable texts or fragments of the texts of sacred books (Scriptures) of this particular religion.

IV. Reputational image of the religion (confession, religious organization) in general, and also generalized reputation character of its believers; the specific lexical structures and words recognizably indigenously belonging to particular religion and/ or the religious organization representing it, including the names of religion and its believers, titles of its religious attendants, etc.;

V. Objectified images and icons honored by believers:

a. Image of an icon (including copies, photo, or reproduction);

b. Statues, bas-reliefs, and other sculptural or architectural objects representing or containing the main and most honored religious symbols or objects in relation of which believers carry out religious worship or religious honoring or concerning which believers are most sensitive;

c. Visual images of the honored by believers religious symbols of religion and/or the religious organization representing it;

d. Material or virtual (by means of computer technologies) objectification of an image of the person in relation of which believers carry out religious worship or religious honoring, or express special religious respect, - visual images (photos, pictures, drawings, etc.), audiovisual, and also text images;

e. The recognizable piece of music which is historically used for liturgy, for worship singing, etc. in this particular religion.

VI. Religiously honored or respected by believers (or by means of which believers carry out religious honoring or express respect) material objects of religious purpose or other material objects, integrally connected with religious practices and/or religious feelings (experiences) of believers:

${ }^{9}$ Ponkine IV. La qualification de discrimination etd'incitation à la hainereligieusesdans les œuvres de fiction télévisuelle: l'exemple de la diffusion de la sériePapetownen Russia.Annuaire Droit et Religions Universitéd'Aix-Marseille; Faculté de Droit et de Science Politique. - Années 2012. 2013;6(1):257-272. 
a. Christian cross as a material, independent (in the material embodiment) object, including - as a sculptural object (in Christianity);

b. Actually, the building or construction of religious (cult liturgical) purpose, even ruined and/or temporarily not used for the initial religious purposes;

c. Internal and external specific (recognizably indigenous for this particular religion) religious decoration of the building of religious purpose, ${ }^{10}$ and equally separate recognizable elements of the decor with religious symbols;

d. The icon, as it is, as a material object with historical and cultural value;

e. Relics of the sacred in Christianity;

f. Building or construction used in the support of the religious activity of the religious organization, though with no cult liturgical mission;

g. Religiously honored place of burial of the person in relation of which believers carry out religious worship or religious honoring or express special religious respect;

h. The land plot which is historically directly connected with religious practices and church services (the site where, earlier, there used to be a building of religious (cult liturgical) purpose; a land plot in relation of which religious practice is provided for construction (in accordance with the established procedure) of the building of religious (cult liturgical) purpose;

i. Freestanding intending crosses (stand-alone or group);

j. Confessional (religious) cemeteries, confessional sites of public cemeteries, religious symbols on cemeterialtumulary constructions, constructions in the form of a recognizable religious symbol;

k. Cenotaphs with religious symbols, religious texts, or images on roadsides of highways or near those (cross, small chapel, stele, bas-relief, etc.), including - in rocky deepenings;

1. An object of natural origin with the attributed religious features connected with this particular religion (the Black stone of the Kaaba, etc.);

m. Objects of direct ceremonial, liturgical purpose -integrally used in the course of religious practice, church service (in Orthodox Christianity - antimension, eucharistical Lamb, ostensorium, shroud, etc.); cult (in the Orthodox Christianity - church) utensils in the building of religious purpose;

n. Specific religious (including - liturgical) canonicals of the priest (religious attendant) of this particular religion or a recognizable element of such canonicals;

${ }^{10}$ Lists and classifications of immovable property of religious purpose are investigated in the works of RV Tupikin and VV Bagan. See: Tupikin RV.Civillaw and contractual regulation of property relations of religious organizations in foreign states.Moscow: BukiVedi, 2016. p. 179.Tupikin RV. The Question of the Legal Nature and Status of Real Estate Objects for Religious Purposes.Stato, Chiese e pluralismoconfessionale. 2016;41.Bagan VV. Property for religious purposes: civil-law view. Moscow: BukiVedi. 2017. p. 208; Bagan VV. On legal and factual grounds of relevance of confessional cemeteries and religious sites of common cemeteries to real estate property objects for religious purposes.Stato, Chiese e pluralismoconfessionale. 2017. p.4. o. Material objectification (embodiment) of the sacred or religiously honored book - a particular copy of such book of the typographical edition or handwork, as possessing independent historical and cultural value, and other;

p. Prayer books (in the Orthodox Christianity - the books for church services containing rites of services and liturgical authorized instructions);

q. Specific materials or products which are specially prepared and used for liturgical purposes (holy water, prosphora in Christianity, etc.);

r. The premises which became the place of religious respect or even religious pilgrimage in which, earlier, the person, in relation of which believers carry out religious worship or religious honoring or express special religious respect, used to live.

VII. Religious order (autonomous order - as a form and part of the social order within the sphere of autonomous standard competence of the religious organization):

a. Civic (autonomous religious) order connected with carrying out religious practices and religious ceremonies (both in buildings or rooms of religious purpose and putside them). In relation of such ceremonials and ceremonies (church service, confession) believers are especially sensitive, and any attempts of intervention in carrying out such ceremonials and ceremonies or attempt to militate against carrying out are treated by them as offensive to their religious feelings.

b. A special autonomous religious order ${ }^{11}$ concerning some allocated parts of the building of cult liturgical purpose burdened with special protection (the room of the altar, etc.).

\section{Conclusion}

The public relations regarding public expression of opinions and dissemination of information on the persons, specially religiously honored by the Russian Orthodox Church believers, are characterized by existence of the legal regulation including legislative measures of legal protection of believers' religious feelings against the insult (for Russia - part 5 of article 13 and part 2 of article 29 of the Constitution of the Russian Federation, part 6 of article 3 of the Federal Law "On Freedom of Conscience and Religious Associations", articles 148 and 282 of the Criminal Code of the Russian Federation of 13.06.1996 No. 63-FZ (edition of 29.07.2017)). While understanding of religious honoring and of the form of its expression can be various in different religions, the religious honoring which is carried out by believers in relation to the objects, religiously, especially valuable to them, is a form of realization of the constitutionally guaranteed freedom of consciousness and is subject to legal protection established by the constitutions and criminal codes of democratic constitutional states of the world. And provided by the criminal law (for example, articles 148 and 282 of the Criminal Code of the Russian Federation), penal prohibition of the offence of religious feelings of believers given in the form of public actions expressing obvious and rough disrespect to the society, and the liability for such acts, are a guarantee of the state protection of the rights and the dignity of believers. However understanding of the issues specified in the article and applying of this understanding in the law-enforcement practice will provide more

${ }^{11}$ Ponkin IV. Autonomous non-legal normative order in the sphere of religion and state protection of religious feelings and dignity of believers. Religion and Law. 2014;3:8-11. 
effective protecting of religious feelings of believers, but thus it will provide avoiding overstepping the legal and actual bounds, avoiding infringing other constitutionally guaranteed fundamental rights and freedoms of the person, first of all - the freedom of expression, artistic expression, and speech.

\section{Acknowledgments}

None.

\section{Conflicts of interest}

The author declares that there is no conflict of interest.

\section{Funding}

None. 